\title{
Against Privatizing Schools in the United Kingdom
}

\author{
HARRY BRIGHOUSE \\ University of Wisconsin, Madison, USA
}

ABSTRACT This paper argues against two models for privatizing schools in the UK: contracting out the management of schools to private companies, and voucher schemes. Contracting out cannot yield the efficiency benefits that are claimed for it, because the contracting process cannot be sufficiently competitive and the government cannot have sufficient knowledge of what makes schools successful to manage the contracts well. Vouchers will not work because the private sector in the UK will not be willing to participate in a scheme which incorporates regulations designed to achieve a minimal level of social justice.

In May 2001 a profit-making public company, NordAnglia, took over the management of a state school in the UK for the first time. Several schools were already run by not-for-profit companies, only because the relevant authorities had judged their bids superior to those of for-profit companies on their merits. Although government rhetoric has varied over time, a recent Green Paper (DfEE, 2001) suggests that the trend to privatization will continue. This is in line with the policy convergence between the two main British political parties on the idea that public services should increasingly be delivered by a mixture of public and private institutions. As Milton Friedman famously observed when first advocating educational vouchers, principled arguments that are normally taken to justify state provision of schooling in fact only support state funding (and regulation) of schooling: who should provide it is not a matter of principle but of pragmatics (Friedman, 1955).

Nevertheless some commentators do oppose privatizing schools on principle. The problem with this approach is that it elevates technical disagreements to the level of principle. The architects of New Labour were right when they argued, against Clause 4 of the Party constitution, that it mistook institutional strategies for political principles. National ownership, whether of banks, railways or schools, cannot be a political principle. Political principles deal with the distribution and the character of liberties, opportunities, resources, and other socially produced goods. So: that every child must have an adequate education to prepare them to be economically active in society is a candidate for a political principle, but that every school should be run by the government is not. The latter statement may be true: but that is a different matter. The political principle must be established by engaging in philosophical argument. The policy must be established by demonstrating that following it would serve the correct political principles better than competing policies.

In the following article, I shall argue against privatization of schools in the UK. I shall consider two models: contracting out (which is the current Government's preferred model), 
and unconstrained vouchers. The first cannot be expected to yield improved efficiency. The second, because it overcomes some of the problems of the first, might yield efficiency gains, but in the context of the UK, can only do so at an unacceptable cost to social justice. Just two words of warning: the case against contracting out depends on showing that the markets it constructs are imperfect. However, it will not do simply to show that market conditions are imperfect, because all markets are imperfect. So it is vital to show that there is something special about the markets constructed by the contracting out model that makes them spectacularly imperfect. Second, I have not said anything yet about the content of educational justice. I believe the same principle of educational justice that the Government proclaims, namely that social background should not influence a child's prospects for educational attainment. I shall not argue for that here-I have done so in detail elsewhere (Brighouse 2000, 2002). The case against contracting out does not depend on this conception of educational justice. The case against vouchers does.

\section{Markets in Compulsory Education}

What is the case against involving profit-making companies in running schools? Stephen Pollard quotes a comedian who humiliates hecklers by asking 'who cuts your hair? the council?' Pollard goes on: 'how we all titter. But what about this: who educates your kids? The council?' Pollard does not, actually, argue against having councils run schools, just that the private sector should be given an equal chance (Pollard, 2000, p. 6). James Tooley nicely picks up another analogy from Michael Barber, who some years ago wrote a newspaper article impugning markets by referring to the difficulty he had finding a good plumber on New Year's Eve. Apparently, he eventually found one who messed the job up, causing him even more expense and inconvenience. Tooley rightly takes him to task for failing to note that he at least has the option of not using the offending plumber next time, an option he would not have if the state were the sole provider of plumbing services (Tooley 2000, p. 130). I concede the case for markets in, and private provision of, plumbing and hairdressing. But schools are not analogous. The bulk of this section is devoted to demonstrating the 'dis-analogy'.

There is nothing, in principle, wrong with markets. Left-wing opponents of privatization often talk as if markets are the problem. Markets are said to be intrinsically competitive, to create winners and losers, to depend on willingness and ability to pay, or to produce outcomes that are 'literally outside anybody's control' (Ranson, 1993, p. 335, see also Tomlinson, 2001). But whether they do so, and the extent to which they do so, depends on the background conditions, including the regulatory frameworks within which they operate, the characters of goods they produce and distribute, and what the other feasible arrangements for the distribution of those goods are. It's plausible, for example, to say that the markets in the production and sales of automobiles have, thanks partly to their own intrinsic features and partly to the way they have been regulated in California, produced only winners: all cars on the market are safer, more durable, and cheaper to run (even accounting for changes in fuel tax levels) now than they were 20 years ago: and more people can afford to buy and run them. If there have been social and environmental costs as the automobile has taken over, this is plausibly attributable to the decisions of governments to provide massive subsidies to the running costs of automobiles, and the success of corporations in seeking rents from the state, rather than the workings of the market itself. There are similar cases with many other consumer durables that are dependent on technology. The creation of winners and losers in markets for consumption goods (as opposed to labor markets) is an artifice of the background distribution of income and wealth: if income and wealth were distributed equally, the markets for consumer goods would not create winners and losers at 
all, they would simply allocate goods efficiently to people facing equal budget constraints (see Dworkin, 1981, 2000).

In their critique of Public Private Partnerships (PPPs), Allyson Pollock et al. (2002) argue that profits represent a net loss to the service that is privatized. After all, the profits have to come from somewhere, and if the system is already stretched, the only place profits can come from is by squeezing services or getting workers to work harder without compensating them. If the workers were overpaid that might be acceptable but there is no reason to believe this, at least of teachers in the UK today. Pollock's argument probably has considerable empirical force. But it is a contingent argument, which certainly needn't be true. Competition might spark innovation, improving productivity without making anyone work harder, to the benefit of all. It is important then to show, as I do in section 2, that there are general reasons for doubting that privatization will enhance efficiency.

James Tooley $(1995,2000)$ has argued for the complete privatization of education. By this he means that the government should abandon all three of its central functions: funding schools, regulating them, and providing them. I agree with critics who claim that complete privatization would result in a worsening of educational injustice, in particular because without government funding and regulation it would be impossible for the government to ensure educational equality (see, for example, Brighouse, 1998). But it does not follow that partial privatization, and in particular withdrawal from the provision of schooling, will have that consequence. From the impropriety of complete privatization we cannot conclude anything about the propriety of partial privatization.

If markets are appealing it is because they are thought to work efficiently, or more efficiently than other available mechanisms. Markets in schooling are troubling for two reasons. First of all, efficiency is only desirable within the constraints described by justice: it may be inefficient, for example, to educate children with disabilities, but that does not count against doing so, because justice requires that we educate them and do so well. The second problem, on which I shall focus in the case against contracting out, is that educational markets are by their natures highly imperfect. This may not mean that markets are more inefficient than other mechanisms. But it does mean that there is more of a burden of proof on advocates of markets and privatization in particular, than they have met.

\section{The Contracting-out Model}

The first model I criticize is the more important, because it is the one that the UK Government is currently using. The Government judges a school to be failing, and then contracts out its management to a private company selected in a competitive tendering process. Some advocate extending the model to non-failing schools. The details of the contracts vary, but the basic arrangements within which the school is enmeshed are unchanged. For example, the same mechanisms that existed before the privatizations allocate children to schools. Hitherto, the Government has provided quite substantial investment into each privatized school, and this makes it hard to evaluate how successful the privatization interventions have been. This practice is not sustainable in the midst of widespread privatization: the Government can give $£ 1$ million to a handful of privatized schools, but not to hundreds or thousands of them. This model assumes market conditions that are neither present nor possible.

First, consider how markets in schooling must be imperfect. Schools must be above a certain size to be viable, so supply is inevitably restricted, and none will be exactly what the consumer wants. Any particular consumer has at most five or six schools that they can realistically consider. By contrast it is usually feasible to employ any of numerous barbers or plumbers. The highly limited supply is a serious market imperfection. So is the fact that once a 
child is at a school there are huge costs (to the education of the child, which is what matters) associated with moving to another school. The costs associated with switching barbers, or plumbers, are trivial (assuming one has one's home insured against certain accidents, and excepting those few people whose professional livelihoods depend on exceptionally high quality hair care). The costs of bad schooling are difficult if not impossible to recoup: the costs of bad plumbing are relatively straightforward to recoup, and the costs of bad barbering are so trivial that nobody even tries to recoup them. No one is perfectly informed about schools, and most people are not even well informed, because good information is very hard to come by. The relevant information is highly peculiar in that it needs to divulge not just how good the school is, but how high the probability is that it will be good for one's own child. Because of the unavoidable morally hazardous issues, there is no insurance market against bad schooling, nor could there be one. The UK system, furthermore, allows selection of pupils by schools, which constitutes another market imperfection. Neoclassical theory assumes that firms are price takers, who cannot decide which customers to take and which to reject. Yet the peer group constitutes part of the product of the school, so by selecting customers the school is able simultaneously to differentiate its product. Many state secondary schools in the UK make much of their academic exclusivity in their formal marketing, and many more do so informally (see Ball [2003], and also, for a magisterial account of the moral dimensions of choosing schools, Swift [2003]).

I should concede at once that privatization may be a legitimate tool for improving identified failing schools. There is no evidence that privatization has helped even failing schools in the UK. However, the sample is small, the privatizations are recent, and they have been accompanied by such significant additional spending by the Government that even when there has been time for improvements to take effect it will be difficult to disentangle the effects of the privatization from the effects of the extra funding. I shall put aside questions about failing schools for the moment, and outline the problems with contracting out as a general policy.

Education policy is intrinsically political: voters and politicians insist that schools must be democratically accountable. And they are right to do so, because education must be distributed justly, and the justice of its distribution cannot be held hostage to the wealth, or the choice-making, of parents. Whereas companies producing consumer goods-or services such as plumbing and hair care-do not need to be regulated to ensure that their goods are distributed justly, because justice is achieved so long as the background pattern of wealth distribution is just and the distribution of goods and services reflects the choices individuals have made about what to do with their wealth, companies producing education do need to be regulated, quite stringently. So contracts awarded to private companies must be short-term, so that incompetent companies can be sacked. It also means that companies will face an ever-changing regulatory regime. Short-term contracts are also needed to ensure that companies face realistic competitive pressures. In free markets companies constantly face multiple competitors for multiple consumers. Without such competitive pressure there is no reason to expect them to deliver any more effectively than the old-fashioned state sector. But because short-term contracts and constantly changing regulations make the contracts unappealing, there will be only a few bidders for them. Nevertheless, the reason the government expects to get better, cheaper delivery from the private sector is that there will be competition for the contracts from multiple bidders. The necessary terms of the contracts ensure that there will not be a truly competitive tendering process.

The government must try to overcome this problem by using long-term contracts which include termination clauses specifying particular outcomes to be met by certain dates. This strategy has two difficulties. The first concerns the character of the termination clauses. Whatever outcomes they specify become the highest and most urgent priority of the 
contractor. So the contractor is highly likely to meet them, regardless of how well it is performing overall. So the government must ensure that whatever is included in the termination clause is a good proxy for overall performance. I am skeptical that it can do so reliably, for reasons I shall explain below. But suppose it does so successfully? Then it has effectively turned a long-term contract into a series of iterated short-term contracts: the appearance of long-termism is an illusion. The second problem with this strategy is that having termination clauses does not render the contract truly competitive unless there are alternative providers on the sidelines waiting to jump in, and whom the government has good reason to suppose will do better. Again, I shall explain later why this is unlikely to be the case even in a system of widespread contracting. It is enough here to note that it is not the case now.

Short-term contracts have other disadvantages. Companies lack incentives for long-term planning and investment, since they have no assurance they will reap the benefits. This is a reason for continued under-investment in the rail infrastructure. When they need investment, they will call on the government to provide it, so we end up either with government control under another name or, as with the rail system, government subsidies for shareholder dividends.

Nor can companies be sure that, even if they succeeded spectacularly, they would be able to keep the profits: imagine the public outcry if NordAnglia announced that it was making $£ 1$ billion a year in profits from its government contracts with schools. Imagine the pressure there would be for a windfall tax. The current Labour Government would probably resist that pressure. But it will not always have a massive majority, and if it had to enter a coalition with another party, or had to rely on its own left wing in order to cling to power, it might find it politically expedient to bow to this pressure. The companies themselves are aware of this possibility, and this is another disincentive for long-term investment.

Additionally, education is a highly skilled labor-intensive business. In this it differs from some of the other functions that have been relatively smoothly contracted out to private companies by local governments, like waste disposal. Governments (in most developed countries) have traditionally been able to purchase this skilled labor at a very low cost for three reasons. First, talented women had few other opportunities than teaching, so were willing to work for artificially low salaries. Second, teachers had a public service ethic. Their sense that their job was socially valuable encouraged them to work for less money than their talents could command elsewhere. Third, teachers were willing to forgo earnings in exchange for job security, or tenure [1].

The first of these conditions has disappeared, probably forever. But the others would be undermined by the widespread use of for-profit companies. A company whose contract lasts only five years can guarantee its workers their jobs for exactly five years, no more. And no one working for a for-profit company will-or should—be willing to exploit themselves for the good of the company. Whereas a state-employed teacher might believe that her low salary frees up public funds for other valuable services, one employed by a private company knows that she is just working for the profit of the shareholders. The involvement of forprofits in the delivery of such public services as education and health will undermine the public service ethic, at huge financial cost to the taxpayer, and moral cost to the country.

Finally, the central efficiency-yielding mechanism in perfect markets is consumer sovereignty. Consumers decide which firms to patronize, which in turn expand, contract, or go bust, in response to demand. Contracting out contains no analogous mechanism. The government, not consumers, decides which firms will run the schools and for how long, and there is no mechanism for ensuring that schools no one wants to patronize will go out of business. Schools are guaranteed that they will have pupils, because the government retains complete control of the supply of places, and will avoid the extra capacity needed to 
promote competition as wasteful; competitors are not allowed to expand to meet demand. So, in fact, most failing schools, including most that have been contracted out, have as the vast majority of their pupils children whose parents chose to send them elsewhere.

Now to the most important point. What judgment is the government making when it decides whether to continue, or withdraw, a contract (or to enforce a termination clause)? First, it is judging not by the popularity of the school, nor by the profit margin, but by its own standards of excellence. Second, it is judging not how well the school was managed but how well it was managed relative to other feasible alternatives. It is, in other words, making a counterfactual judgment. Consider a termination clause which insists that half the children are getting 5 Cs or more at GCSE by year 4 of the contract. Suppose that by year 4 only $25 \%$ of children are performing at the target. It would be irresponsible to invoke the clause unless the government had reason to think that some other contractor would have done better [2]. But that may be quite implausible: and even if it is plausible the officials in charge have a strong incentive to act as if it is implausible, because its plausibility casts doubt on the wisdom of their original judgment. There is a serious information-gathering problem here. It is possible to identify failing schools, and to distinguish excellent from failing schools. But it is extremely difficult to make confident judgments about the relative success of the vast majority of schools that are neither excellent nor failing. It is possible to identify improvement in the worst schools and decline in the best, but even in those schools it is extremely hard to identify whether the improvement is better or the decline worse than it would have been under feasible alternatives. If management of any but the worst schools is put out to contract it will be on the basis of such, basically arbitrary, judgments, that the decisions will be made. But this is a recipe for complacency in the vast majority of schools that fall between the extremes of performance. Unless contracts are terminated, or not renewed, reasonably often, contractors have good reason to rest on their laurels.

The relative paucity of competitors for contracts will not help. Firms running such schools simply will not be held accountable, because the Government simply will not have the relevant information. It may be true that value-added analyses would help with this, but there are currently no viable value-added analyses, and it is proving extremely difficult to construct them, and these difficulties are not trivial. The Government has instituted a scheme that will, in theory, record all relevant data (test/exam results, schools attended and a few other things) concerning every pupil from age 4 to 16 . If these data were accurately gathered, they would, in principle, allow for value-added tables. It is worth emphasizing what a massive data-gathering task this is: for example, since we know that socio-economic background is a predictor of outcomes, quite detailed data on the (relatively frequent) movements between income deciles of children's families would be needed. There are serious problems concerning the effects of pupil mobility, and reasonable doubts that the data can be gathered accurately. But even if these problems are overcome, there remain two insuperable difficulties, as Harvey Goldstein explains:

Schools cannot be summarized by a single value-added score-they are differentially 'effective' for different kinds of pupil and in different subjects ... More seriously, the numbers are smallish so that sampling error gives you very wide uncertainty intervals and this means that for anything between 60 and $80 \%$ of schools they cannot be distinguished from the overall average! Some schools do turn up as extreme but will not all do so over time, and it is also very difficult to detect schools that are changing consistently over time. In other words, for most schools there is no statistically valid way that they can be ranked. Even where you do detect an 'outlier' there may be a good reason for this over which the school has little control. (Goldstein, 2001. See also Goldstein, 1997; Goldstein et al., 2000) 
On the most optimistic assumptions, value-added tables will help only at the extremes, and not for discriminations between the vast majority of schools that fall within the normal range. The IPPR's Commission on Public Private Partnership chair, Martin Taylor, claimed that if privatization would benefit failing schools it should also be able to benefit most other schools (Commission on Public Private Partnerships, 2001). But what we know about the potential for value-added analysis provides a reason for thinking the reverse: because the best that value-added could do is tell us about the relative performance of outliers, and nothing about the relative performance of the rest.

It is worth adding here that parents and governments are trying to access completely different information concerning schools and their performance. Governments simply cannot know, and do not have an interest in, how schools perform for each individual child. They have to take, as a proxy for performance for all children, some pre-chosen standard-the percentage getting 5 or more Cs at GCSE, or the percentage truanting, or (more eccentrically) the percentage getting a $\mathrm{C}$ or above in GCSEs in both Latin and Woodwork. But a parent is trying to find a balance between a good school and her own child's needs. She may judge that her child will thrive better academically in a not-particularly academic school; or will do better on all counts if separated from her high-flying sibling; or would do better to accompany her supportive and good-natured friends into an overall less well-performing school; or to part from her sniping, aggressive and unpleasant friends attending an overall better-performing school. She might reasonably judge her child to be at minimal risk from peer pressure to truant, so might be unconcerned about a high truancy rate in a school which has a record of good science teaching for girls. Her child may be particularly susceptible to bullying, so she may prefer a school with a good discipline record and mediocre exam results to one with terrific exam results and a culture in which bullying thrives.

I am not trying to suggest that parents are particularly well placed to make these judgments (although they do have great advantages over almost anyone else, including governments, since at least they have access to lots of information about their child), but do want to emphasize that their judgments are about a different matter than that of governments. Governments have no interest at all in what the school does for any particular child, only in their overall quality (which, as I have explained, they are not well-positioned to judge anyway). Making schools vulnerable to the parents' judgments can be done without privatizing, and the UK Government's model of privatization does nothing to make schools vulnerable to these judgments.

These are all quite theoretical reasons for opposing the Government's model of privatization. Supporters tell us to look to the USA where, they say, privatization works. But they are wrong. The USA is a bad model for the UK to emulate, because the state education system is far more expensive, far less efficient, and far more unequal. The regulatory framework and tax system are also much more business-friendly than in the UK, so successful use of for-profits there would not translate to the UK. But, more importantly, the for-profits are not successful at running schools in the USA. There is no evidence that their interventions have been more successful than state-run interventions in similar schools. And they do not even make a profit. The biggest, and most high-profile company involved, the Edison company, does not expect to break even until 2006, and that was before the recent downturn in the economy. In 1999 they posted losses of $\$ 49$ million.

\section{The Voucher Alternative}

Contracting out is not the only available model of privatization. An alternative model is suggested by the former Chief Inspector of Schools, Chris Woodhead, in his recent book Class War (2002). Like many other advocates of privatization he is impressed by a decade-old 
voucher program running in Milwaukee, Wisconsin, in the USA, and suggests that the government should give vouchers to parents, to use at the schools of their choice, whether run privately or by the state. This would have one major advantage over contracting out, which is that parents, rather than the government, would be making the choices about which children went to which schools, so that some of the information-gathering problems that plague the contracting out model would be solved. It would, furthermore, allow unpopular schools to go out of business, rather than having to be closed or, at great cost, intervened in. The expected outcome of this would be that increasing numbers of children would attend existing (or, over time, new) private schools, which are usually run by non-profit-making foundations. Private schools already exist and have a great deal of expertise, with which state schools would have an incentive to compete. Vouchers might even help to efface the iniquitous distinction between state and private schooling, by drawing private schools into the vital public mission of educating all the children in our society.

There are for example, a handful of small private voucher programs in the USA — as well as the Milwaukee scheme there are programs in Cleveland, Ohio and in Florida, which allow children ill-served by the state sector to attend private schools on government funds. These schemes, the argument goes, work well, so why not use them as a model for the UK?

The Milwaukee scheme is the longest lasting, and most carefully scrutinized of these schemes. It now serves several thousand students, almost all of them Black and Latino and all of them, by law, from low-income families. The private schools which take vouchers are not allowed to charge any more than the cost of the voucher, and are not allowed to select among the children who apply on grounds of ability, past behavior, religious affiliation, or any other grounds. The effects of the program on student achievement are disputed, and this dispute is very hard to evaluate because after the first five years of the program the State stopped requiring voucher schools to make achievement data available. But on most accounts, although the scheme appears to have, at best, limited achievement benefits, no-one claims there are achievement losses, and this is despite the fact that the children are educated at only two-thirds of the costs of the state schools. Furthermore, there are non-achievement-related benefits which are harder to measure: the sense of relief parents have from extracting their children from unsatisfactory, and sometimes dangerous, situations; the benefits they get from feeling more involved in their children's education; and the fact that the children are attending small schools, with teachers they and their parents can actually get to know (Witte, 2000; see also Brighouse, 2000, chapter 8, for a detailed discussion of the Milwaukee program).

Assume (implausibly) that the optimism for the Milwaukee scheme is right, and that it causes measurable improvements in the achievement and well-being of poor children, at significantly lower cost to the taxpayer. If this were true, it would be very strong evidence in favour of maintaining, and perhaps extending, the scheme in Milwaukee and similar areas. Raising the achievement of socially disadvantaged children is one of the most important goals of an egalitarian educational policy. But even if the optimists are right, this does nothing to justify importing the model to the UK.

Why? The main reason is that the structure of both the private and the state sectors in each country are completely different, so that the benefits vouchers might yield in the USA cannot be expected to be replicated here. What are the differences?

First, and most crucially, the private sector in the USA is replete with small, low cost providers, which do not select by class or academic ability. Per-pupil spending in US private schools is, on average, about half per-pupil spending in US state schools (and in voucher schools it is even lower, because no expensive elite private school participates in the scheme). In the UK, by contrast, per-pupil spending in private schools is double that in state schools. To put it simply, the USA has a large sector of private schools which educate at low cost, and want to educate all regardless of ability, wealth or behavior. The UK does not. 
Second, and related to this, within the US public schools (the state system) there is an outrageous inequality of spending: because of local funding, state schools in wealthy suburban neighbourhoods routinely spend twice, and sometimes three times, as much per pupil than schools in poor urban settings which deal with children with much higher needs. In the USA it is the public school system itself which is the central culprit in the perpetuation of educational injustice. The private sector, because it has so many low-cost providers, often helps to ease the injustice by allowing an exit option for middle-low income children.

Woodhead's proposal is vague. It seems to be modeled on the nursery voucher scheme, in which the government gives a flat-rate voucher for each child, which the parent can then use at whatever school she chooses. The school can charge extra money in addition to the voucher, and can select which children to accept. So the voucher is effectively a subsidy for those who already use private schools, and there is limited parental choice, because schools, rather than parents, have the final say on where children attend school. But vouchers need not be like this. We can imagine means-tested vouchers which are very high for the very poor, but phase out for those with incomes over, say $£ 75 \mathrm{k}$. We can imagine that all voucher schools have to select children by lottery, and have no discretion over admissions at all (as occurs, in fact, in the Milwaukee scheme Woodhead appeals to).

So it is vital to note the different attitudes of the sectors in the two countries to control over admissions. The historic US policy of favoring Protestant schools in the public sector gave rise to a large and robust sector of private Roman Catholic schools, which saw it as part of their mission to educate all sectors of society: and this sector has remained despite the change in tack of ejecting all reference to religion from state schools. The Roman Catholic diocesan and order-run schools comprise over half the schools in the Milwaukee program. Serving the poor is a central part of their mission. These schools lobbied to be included in the voucher scheme even though it was clear that they would not be allowed to discriminate at all among the low-income applicants: oversubscribed schools are not allowed to select on grounds of religious affiliation, academic ability, race, or behavioral history.

By contrast, while the lobbyists for UK private schools are enthusiastic about state subsidies for private school attendance, they consistently resist any measures that would compromise private schools' control over their own admissions process (Davison, 2001). The consequence of this must be that they will only accept students whom they can educate at the cost the state will provide. Since their per-pupil costs are double what the state pays to educate children in its own schools, this must mean that they will be willing to take only those children who are inexpensive to educate: the most able children who have few behavioral problems. It is hard to imagine how the UK private sector could accept a voucher system that is consistent with social justice: which requires that schools embrace the mission of educating all children, and not only those who can be educated easily and inexpensively.

Politically, this is important. While a progressive voucher program regulated the right way could, in principle, promote equality, in practice any efforts to press for such a voucher scheme are likely to founder. Legislation would be amended to accommodate the demands of the private schools (whose cooperation would be needed to make it work). The most likely outcome is that political pressure for progressive vouchers would simply yield state subsidies for the private sector.

\section{Conclusion}

The two most obvious models for privatizing schools in the UK are deeply flawed. Contracting out lacks the crucial mechanism of consumer sovereignty, and assumes that the 
government can make judgments about the relative performance of schools about which it, in fact, has no information. While progressive voucher schemes are conceivable, they are highly unlikely to emerge from the process of policy-making, and anyway, even if they did, hardly any of the currently existing private sector would participate. Privatization, quite simply, is not a solution to the problems of state education in the UK.

Correspondence: Professor Harry Brighouse, 5119 Helen C White, 600 N Park St, Madison, WI 53706, USA.

\section{Acknowledgements}

Thanks to an audience at the Social Market Foundation for comments on a predecessor of this paper, and to Adam Swift, Harvey Goldstein and two anonymous referees for helpful comments.

\section{Notes}

[1] Thanks to Avner Offer for making these comments to me, which he in turn attributes to Martin West.

[2] Harvey Goldstein has pointed out to me that this is precisely what the successive governments have done with so-called failing schools, which they have closed and reopened under the New Start initiative. I do not mean to imply that governments will not behave irresponsibly, only that if they do then one of the supposed benefits of privatization will suffer.

\section{References}

Ball, S. (2003) Class Strategies and the Education Market, London, RoutledgeFalmer.

Brighouse, H. (1998) Why states should fund schools, British Journal of Educational Studies 46, 1, $138-151$.

Brighouse, H. (2000) School Choice and Social Justice, Oxford, Oxford University Press.

Brighouse, H. (2002) Egalitarian Liberalism and Justice in Education, London, Institute of Education.

Commission on Public Private Partnerships (2001) Building Better Partnerships, London, IPPR.

Davison, R. (2001) What the government should do for independent schools, letter, New Statesman, 15 January.

DFEE (2001) Schools: building on success, Norwich, The Stationery Office.

Dworkin, R. (1981) What is equality? Part 2: equality of resources, Philosophy and Public Affairs, $10,283-345$.

Dworkin, R. (2000) Sovereign Virtue, Cambridge, MA, Harvard University Press.

Freidman, M. (1955) The role of government in education, in R.A. Solo (ed.) Economics and the Public Interest, New Brunswick, Rutgers University Press.

Goldstein, H. (1997) Value added tables: the less-than-holy grail, Managing Schools Today 6, 1, $18-19$.

Goldstein, H. (2001) personal communication, Nov 21.

Goldstein, H., Huigi, P., Рath, T. \& Hill, N. (2000) The Use of Value-Added Information in Judging School Performance, London, Institute of Education.

Pollard, S. (2000) Should private firms run state schools? Yes, Fabian Review, 112, 3, 6.

Pollock, A., Shaoul, J., Rowland, D., \& Player, S. (2002) Public Services and the Private Sector: a response to the IPPR, London, Catalyst. 
Ranson, S. (1993) Markets or democracy for education, British Journal of Educational Studies, 41, $4,333-352$.

Swift, A. (2003) How Not to be a Hypocrite: school choice for the morally perplexed, London, RoutledgeFalmer.

Tooley, J. (2000) Reclaiming Education, London, Cassell.

Witte, J. (2000) The Market Approach to Education, Princeton, NJ, Princeton University Press.

Woodhead, C. (2002) Class War, London, Little Brown. 